\title{
Gender Difference in Distribution of Estrogen and Androgen Receptors in Intestinal-type Gastric Cancer
}

\author{
ZORAN JUKIC $^{1,5^{*}}$, PETRA RADULOVIC ${ }^{2 *}$, RANKO STOJKOVIĆ ${ }^{3}$, AUGUST MIJIC ${ }^{2}$, JOSIP GRAH ${ }^{4,5}$, \\ BOZO KRUSLIN ${ }^{2,6}$, ZELJKO FERENCIC ${ }^{7}$ and ALEKSANDRA FUCIC ${ }^{8}$ \\ ${ }^{1}$ General Hospital Nova Gradiska, Nova Gradiska, Croatia; \\ ${ }^{2}$ Sestre Milosrdnice University Hospital Center, Zagreb, Croatia; \\ ${ }^{3}$ Rudjer Boskovic Institute, Zagreb, Croatia; \\ ${ }^{4}$ Rebro, Clinical Hospital Centre, Zagreb, Croatia; \\ ${ }^{5}$ School of Medicine, J.J. Strossmayer University of Osijek, Osijek, Croatia; \\ ${ }^{6}$ School of Medicine, University of Zagreb, Zagreb, Croatia; \\ ${ }^{7}$ Srebrnjak Clinical Hospital, Zagreb, Croatia; \\ ${ }^{8}$ Institute for Medical Research and Occupational Health, Zagreb, Croatia
}

\begin{abstract}
Background: Gender difference in survival of patients with gastric cancer is not well investigated. The aim of this study was to analyze the gender-related distribution of estrogen receptor alpha $(E R \alpha)$ and androgen receptor $(A R)$ in the epithelium and stroma of intestinal-type gastric cancer. Materials and Methods: Immunohistochemical analysis was performed in 60 patients ( $42 \%$ females). Results: In gastric cancer patients, frequency of ER $\alpha$ positive cells was lower in epithelium than in healthy individuals, but not significantly. In stroma and epithelium, AR-positive cells were absent from samples of women with $T 1$ and $T 2$ stage disease, while in men, their frequency was significantly increased in stroma of those with T3 and T4 stages and was significantly higher compared to women. AR-positive cells in stroma were fibroblasts, myofibroblasts and mast cells. Conclusion: To our knowledge, this study is the first to show gender differences in the distribution and frequency of AR-positive cells in neoplastic stroma of gastric cancer.
\end{abstract}

Major risk factors for developing gastric cancer are infection with Helicobacter pylori, peptic ulcer, dietary habits, ionizing radiation, smoking, alcohol and pernicious anemia

\footnotetext{
*These Authors contributed equally to this study.

Correspondence to: Aleksandra Fucic, Institute for Medical Research and Occupational Health, Ksaverska c 2, 10000 Zagreb, Croatia. Tel: +385 14682500, e-mail: afucic@imi.hr

Key Words: Intestinal gastric cancer, estrogen receptor, androgen receptor, stroma, mast cell, myofibroblast.
}

(1-3). Despite the global reduction in gastric cancer incidence and mortality (4), it is still one of the leading causes of cancer death (5).

Men exhibit a higher incidence and mortality of gastric cancer than women $(6,7)$. Therefore, the role of testosterone and estrogen in gastric cancer etiology, response to therapy and survival have been investigated during the last several decades, but the involved mechanisms and pathways still remain unclear. Data regarding the level of ER $\alpha$ in gastric neoplastic tissue in comparison with normal gastric tissue are still contradictory (8-12). The expression of $E R \alpha$ and $E R \beta$ mRNA has been shown to be related to a poorer prognosis and increased metastatic potential of gastric cancer (10-13). It has additionally been shown in an animal model that estrogen directly promotes apoptosis in gastric cancer (14) and reduces the size of gastric lesions caused by $\mathrm{H}$. pylori, probably by enhancing the function of interleukin (IL)-10 thus decreasing expression of interferon- $\gamma$ and IL1 $\beta$ a induced by H. pylori (15). The expression of ER $\alpha$ in in vitro experiments with MKN28 gastric cancer cells was associated with the promotion of apoptosis and inhibition of cell growth (16).

Recent studies have shown that the AR is involved in a number of pathways associated with carcinogenesis of tissues other than reproductive organs. Overexpression of AR seems to promote carcinogenesis and has been reported in association with lymph node metastases and poor prognosis $(17,18)$. Studies analyzing neoplastic gastric tissue have found positive AR reaction to correlate with poorer survival but not with other clinicopathological parameters $(17,19$, 20). An experimental model in rats showed that testosterone delayed the healing of gastric ulcer and increased plasma levels of IL $1 \beta$ and tumor necrosis factor $\alpha$ (21). 
The expression of sex hormones is correlated with other molecules described in neoplastic tissue and relevant to the etiology and therapy of gastric cancer. Thus, susceptibility to developing gastric cancer has been suggested to be correlated with a decreased expression of the trefoil factor 1 (TFF1) gene related to polymorphism of the estrogen response element (22).

The significance of stroma in cancer progression and invasiveness has been investigated in different types of cancers. Activation of stroma is generated by invading tumor cells supported by activated fibroblasts and myofibroblasts with a high proliferative rate and capacity to produce different growth factors and cytokines, including those that promote angiogenesis $(23,24)$. As yet, the mechanisms and pathways crucial for the activation of stromal cellular and acellular components are not familiar at a level that would enable the introduction of stromal biomarkers as prognostic parameters or drugs with impact on the elimination of stromal elements in angiogenesis or metabolic support for neoplastic cells. It seems that stromatogenesis occurs simultaneously with the neoplastic process at the invasive front of an active tumor and at sites of tumor metastasis (25).

The aim of this study was to investigate the distribution of $\mathrm{ER} \alpha$ and $\mathrm{AR}$ in stroma and neoplastic epithelium in patients with intestinal-type gastric cancer. Although both $\operatorname{ER} \alpha$ and $\operatorname{ER} \beta$ have been described in gastric cancer, this study analyzed ER $\alpha$ because of its suggested association with cancer invasiveness and as further investigations are still needed due to contradictory findings $(13,26,27)$. In order to obtain better insight into the gender difference in intestinal gastric tumor biology, both male and female patients were included in the study. The aim of this study was also to compare $\mathrm{ER} \alpha$ and $\mathrm{AR}$ distribution in different stages of intestinal gastric cancer.

\section{Materials and Methods}

All procedures were performed in accordance with the ethical standards of the national regulations and with the 1964 Declaration of Helsinki and its later amendments or comparable ethical standards. This study was approved by the Ethical Committee of Sestre Milosrdnice University Hospital Center, Croatia (no. EP1538913-9). This article does not include any studies with animals performed by any of the Authors. Tissue specimens used in the current study were part of the hospital tissue archive. For this type of study formal consent is not required.

In this study, 60 histological specimens from patients with intestinal-type gastric cancer were analyzed, of which 26 were from women and 34 from men. Stages from T1N0 to T4N2 were included. Comparison of results was performed based on Lauren's classification (28) between those with $\mathrm{T} 1$ and $\mathrm{T} 2$ versus those with $\mathrm{T} 3$ and T4 stages. The mean age of patients was 69 years (range $=35-90$ years). All neoplastic tissue specimens were obtained before anticancer therapy.
Resected tissue specimens were formalin-fixed, paraffinembedded and cut on a microtome to form tissue sections (thickness $5 \mu \mathrm{m}$ ) which were routinely stained with hematoxylin and eosin dye. Immunohistochemical analysis was performed after tissue section deparaffinization following the microwave streptavidin immunoperoxidase protocol and using labelled streptavidin-biotin method on a DAKO TechMate ${ }^{\mathrm{TM}}$ Horizon automated immunostainer. Monoclonal antibodies against ER $\alpha$ (Dako, Glostrup Denmark) and AR (Abcam, Cambridge, UK) were used. Human breast cancer tissue expressing ER $\alpha$ and human prostate cancer tissue expressing AR were used as positive control. Negative control was performed by incubation of sections without primary antibody.

The scoring of nuclear and cytoplasmic immunoreactivity in cancer epithelium and stroma was performed as follows $(20,29)$. $\mathrm{ER} \alpha$ - and AR-positive cells in cancer epithelium and stroma were classified into the following two groups: positive, more than $10 \%$ positive cells; and negative, fewer than $10 \%$ positive cells or no immunoreactivity. The evaluation was performed by two of the authors (BK and PR), independently. Discordant results between the investigators were re-evaluated together. The AR scoring in carcinoma cells was performed on high-power fields $(\times 400)$ using standard light microscopy. In each case, more than 500 carcinoma cells were counted. Percentage of immunoreactivity, i.e. labelling index (LI), was determined. Cases with more than $10 \%$ LI were regarded as positive and cases with less than $10 \%$ LI as negative. In order to estimate difference in frequency of ER $\alpha$ - and ARpositive cells in epithelium and stroma and to compare frequency between genders and TN stages, statistical analysis was performed using Kruskal-Wallis ANOVA test.

\section{Results}

Expression of ER $\alpha$ and AR was analyzed in 60 patients with intestinal-type gastric cancer staged from T1N0 to T4N2. Of this group, $42 \%$ were female. The average age of patients was $69.8 \pm 13.8$ years for women and $69.3 \pm 10.5$ years for men. Immunohistochemically stained receptors were analyzed in normal and neoplastic epithelium and stroma as well as in the muscular layer of the gastric wall. Immunostaining was observed both in the nucleus and cytoplasm.

Expression of ER $\alpha$ was detected in the neoplastic epithelium, nuclei of fibroblasts within gastric cancer stroma, nuclei of monocytes and lymphocytes, cytoplasm of mast cells and neutrophils, as well as in goblet cell vacuoles in the area of intestinal metaplasia adjacent to the tumor. Positive AR immunoreactivity was detected in the nuclei of gastric cancer cells, cytoplasm of intratumoral and extratumoral mast cells, as well as in the nuclei of myofibroblast cells in the vicinity of blood vessels and at the invasive border of the tumor.

For both genders with T2 or T3 stage tumors, ER $\alpha$ positive cells were present in inflammation. In stroma, ARpositive cells were detected in men in T1, T2 and T3 stages in myofibroblasts next to blood vessels, mast cells, fibroblasts, and lymphocytes.

For both genders, the frequency of cases with ER $\alpha$ positive cells in neoplastic epithelium and stroma was lower 
Jukic et al: Distribution of AR and ER in Intestinal-type Gastric Cancer Patients

Table I. Distribution of frequencies of estrogen receptor $\alpha$ (ER $)$ - and androgen receptor (AR)-positive cells in epithelium and stroma in patients and healthy individuals. p-Values are for the difference in frequency of cases with ERa-/AR-positive cells in epithelium and stroma between genders and cancer stage.

\begin{tabular}{|c|c|c|c|c|c|c|c|c|c|c|}
\hline \multirow[t]{2}{*}{ Stage } & \multirow[t]{2}{*}{ Gender } & \multicolumn{4}{|c|}{ ER $\alpha$-positive } & \multicolumn{4}{|c|}{ AR-positive } & \multirow{2}{*}{$\begin{array}{c}\text { Whole } \\
\text { cohort } \\
78\end{array}$} \\
\hline & & $\begin{array}{c}\text { Epithelium } \\
\mathrm{N}\end{array}$ & $\mathrm{p}$-Value & $\begin{array}{l}\text { Stroma } \\
\mathrm{N}\end{array}$ & $p$-Value & $\begin{array}{c}\text { Epithelium } \\
\mathrm{N}\end{array}$ & $p$-Value & $\begin{array}{c}\text { Stroma } \\
\mathrm{N}\end{array}$ & $p$-Value & \\
\hline \multirow[t]{2}{*}{$\mathrm{T} 1+\mathrm{T} 2$} & M & 3 & 0.48 & 1 & 0.87 & 1 & 0.39 & 2 & $<0.01$ & 10 \\
\hline & $\mathrm{F}$ & 3 & & 1 & & 0 & & 0 & & 9 \\
\hline \multirow[t]{2}{*}{$\mathrm{T} 3+\mathrm{T} 4$} & M & 4 & & 1 & & 5 & & 11 & & 24 \\
\hline & $\mathrm{F}$ & 2 & & 1 & & 4 & & 1 & & 17 \\
\hline Control & & 11 & & 0 & & 5 & & 2 & 0.10 & 18 \\
\hline
\end{tabular}

M: Male; F: female; N: number of individuals with ER $\alpha$-/AR-positive cells.

than in the controls, although the difference was not significant. In women AR-positive cells were absent in those with stage T1 and T2 disease both from the stroma and the epithelium. In men, frequency of cases with AR-positive cells in the stroma was significantly higher in those with T3 and $\mathrm{T} 4$ in comparison to stages $\mathrm{T} 1$ and $\mathrm{T} 2$ and was significantly higher than in women (Table I).

\section{Discussion}

According to the International Agency for Research on Cancer (http://globocan.iarc.fr/old/FactSheets/cancers/ stomach-new.asp), approximately one million new cases of gastric cancer were estimated to have occurred in 2012, making it the fifth most common malignancy in the world. It is the third leading cause of cancer death in both sexes worldwide. Age-standardized incidence rates are about twice as high in men as in women and there is a higher survival rate of women after anticancer therapy.

In this study, the frequency of cases with ER $\alpha$-positive cells in epithelium and stroma was lower than that in the controls, although not significantly. There was no significant difference in frequency of cases with ER $\alpha$-positive cells between $\mathrm{TN}$ stages and gender. In women, AR-positive cells were not detected in stages $\mathrm{T} 1$ and $\mathrm{T} 2$, neither in the neoplastic epithelium nor in the stroma. In men, the frequency of cases with AR-positive cells in stroma with T3 and $\mathrm{T} 4$ stage disease was significantly higher in comparison with men with stage T1 and T2, and with women. As far as we are aware, this study is the first to show that the major difference between men and women in intestinal-type gastric cancer lies in the expression of stromal AR, suggesting that the stroma plays a significant role in gender differences in invasiveness and survival following intestinal gastric cancer.

The gender difference in gastric cancer incidence and survival has so far been suggested originate in gender differences of ER and AR expression in gastric tissue (30, $31)$. The results of this study are in agreement with a recent similar study where a decrease in frequency of ER $\alpha$-positive cells was detected in the neoplastic tissue of patients with stomach cancer $(12,32)$ and correlated with poorer survival prognosis.

It was shown in an animal model that both castration and administration of $17 \beta$-estradiol to male rats reduced the incidence of experimentally-induced gastric tumors. The incidence of gastric cancer in MNNG-treated castrated rats was lower than in $17 \mathrm{~b}$-estradiol treated intact male rats, suggesting not only that $17 \beta$-estradiol may protect against gastric carcinogenesis but also that testosterone may take part in the promotion of gastric cancer (33-35). Additionally, it has been shown that the origin of the higher resistance in women to gastric ulceration caused by stress may have origin in higher levels of estrogen than in men (36). Similarly, the incidence of intestinal metaplasia induced in rats by $\mathrm{X}$ rays was higher in ovariectomized females than in intact ones, and increased in those with testosterone pretreatment and decreased in those pretreated with dimethyl estradiol (37). Presence of inflammation in gastric cancer may also be related with a decrease in estrogen-directed control of immunological defense mechanisms (38). According to recent findings, both ER $\alpha$ and ER $\beta$ mediate in acetic acidinduced gastric damage in rats, play equal and efficient roles in the anti-inflammatory mechanisms of estrogen, and limit the migration of neutrophils to inflamed tissues (39). Some studies have shown that estrogen has an impact on genes related to cell differentiation (40). Using an MKN28 gastric cell line with ER $\alpha$ overexpression, it was shown that ER $\alpha$ reduces the motility and invasion of gastric cancer cells as suggested by a decrease of $\beta$-catenin (16). An in vitro model showed that estradiol reduced the migration speed, apoptosis and cell proliferation of a gastric adenocarcinoma cell line $(16,41)$, and that a physiological dose of estrogen reduced 
granulocyte activity by stimulating NO release by activation of ER (42). Thus, the reduction of ER $\alpha$ and increase of AR in neoplastic tissue reported in our study are in concordance with results of these experimental studies.

There has been increased interest regarding the role of AR in the etiology of cancer and its impact on survival. AR expression has been reported in liver, colon, gastric and brain tumors and better survival is associated with tumor AR negativity (43). Apart from reproductive organs, testosterone has been described as a mitogen in other specific tissues during development, as well as in some neoplasms and in in vitro studies (44-46). It has been suggested that AR-mediated metastasis regulation involves mechanisms via the AKT pathway (43). Interactions between $\operatorname{ER} \alpha, \operatorname{ER} \beta$ and $A R$ in normal and neoplastic gastric tissue are still unknown. However, it has been shown that androgen-synthesizing and -metabolizing enzymes are present locally in gastric cancer tissue (20). The impact of testosterone on cancer-invasive growth is additionally shown as AR-positive cells have also been detected in lamina propria as a significant location for neoplastic growth (47).

The stroma is a crucial milieu both for the homeostasis of healthy tissue and for carcinogenesis. It has been suggested that mast cells in stroma may inhibit the proliferation and dissemination of gastric cancer cells as well as ER-positive mast cells (48) via release of TNF (49). Additionally, estrogen initiates the degranulation of mast cells in stroma and promotes angiogenesis, even in tumors which are ERnegative $(23,50,51)$.

In conclusion, the results of this study showed lower frequency of cases with ER $\alpha$-positive cells in neoplastic epithelium than in controls although, not significant. Significantly higher frequency of cases with AR-positive cells in stroma of intestinal gastric cancer of men than in women may be the main origin of the greater invasiveness of this cancer type in men. AR predominance over ER $\alpha$ in intestinal gastric cancer stroma might be used for future therapies based on AR-targeted agents.

\section{Acknowledgements}

This study was funded by Ministry of Science, Education and Sport of Republic Croatia.

\section{References}

1 Kelley JR and Duggan JM: Gastric cancer epidemiology and risk factors. J Clin Epidemiol 56(1): 1-9, 2003.

2 Massarrat S and Stolte M: Development of gastric cancer and its prevention. Arch Iran Med 17(7): 514-520, 2014.

3 Lee TY, Wang CB, Chen TT, Kuo KN, Wu MS, Lin JT, Wu CY, Taiwan Gastrointestinal D and Helicobacter C: A tool to predict risk for gastric cancer in patients with peptic ulcer disease on the basis of a nationwide cohort. Clin Gastroenterol Hepatol 13(2): 287-293 e281, 2015.
4 Ferro A, Peleteiro B, Malvezzi M, Bosetti C, Bertuccio P, Levi F, Negri E, La Vecchia $C$ and Lunet N: Worldwide trends in gastric cancer mortality (1980-2011), with predictions to 2015, and incidence by subtype. Eur J Cancer 50(7): 1330-1344, 2014.

5 Ferlay J, Soerjomataram I, Dikshit R, Eser S, Mathers C, Rebelo M, Parkin DM, Forman D and Bray F: Cancer incidence and mortality worldwide: Sources, methods and major patterns in globocan 2012. Int J Cancer 136(5): E359-386, 2015.

6 Chandanos E and Lagergren J: Oestrogen and the enigmatic male predominance of gastric cancer. Eur J Cancer 44(16): 23972403, 2008.

7 Nikfarjam Z, Massoudi T, Salehi M, Salehi M and Khoshroo F: Demographic survey of four thousand patients with 10 common cancers in north eastern Iran over the past three decades. Asian Pac J Cancer Prev 15(23): 10193-10198, 2014.

8 Woo I, Park M, Choi S, Kim S, Lee M, Kang J, Hong Y and Lee $\mathrm{K}$ : Loss of estrogen receptor- $\alpha$ expression is associated with hypermethylation near its ATG start codon in gastric cancer cell lines. Oncology Reports, 2004.

9 Gan L, He J, Zhang X, Zhang YJ, Yu GZ, Chen Y, Pan J, Wang $\mathrm{JJ}$ and Wang $\mathrm{X}$ : Expression profile and prognostic role of sex hormone receptors in gastric cancer. BMC Cancer 12: 566, 2012.

10 Takano N, Iizuka N, Hazama S, Yoshino S, Tangoku A and Oka M: Expression of estrogen receptor-alpha and -beta mRNAs in human gastric cancer. Cancer Lett 176(2): 129-135, 2002.

11 Wang Z, Zhang X, Shen P, Loggie BW, Chang Y and Deuel TF: Identification, cloning, and expression of human estrogen receptor-alpha36, a novel variant of human estrogen receptoralpha66. Biochem Biophys Res Commun 336(4): 1023-1027, 2005.

12 Yi JH, Do IG, Jang J, Kim ST, Kim KM, Park SH, Park JO, Park YS, Lim HY, Kang WK and Lee J: Anti-tumor efficacy of fulvestrant in estrogen receptor positive gastric cancer. Sci Rep 4: 7592, 2014.

13 Xu CY, Guo JL, Jiang ZN, Xie SD, Shen JG, Shen JY and Wang LB: Prognostic role of estrogen receptor alpha and estrogen receptor beta in gastric cancer. Ann Surg Oncol 17(9): 25032509, 2010.

14 Qin J, Liu M, Ding Q, Ji X, Hao Y, Wu X and Xiong J: The direct effect of estrogen on cell viability and apoptosis in human gastric cancer cells. Mol Cell Biochem 395(1-2): 99107, 2014.

15 Ohtani M, Ge Z, Garcia A, Rogers AB, Muthupalani S, Taylor NS, Xu S, Watanabe K, Feng Y, Marini RP, Whary MT, Wang TC and Fox JG: 17 beta-estradiol suppresses helicobacter pyloriinduced gastric pathology in male hypergastrinemic ins-gas mice. Carcinogenesis 32(8): 1244-1250, 2011.

16 Zhou J, Teng R, Xu C, Wang Q, Guo J, Xu C, Li Z, Xie S, Shen $\mathrm{J}$ and Wang L: Overexpression of eralpha inhibits proliferation and invasion of MKN28 gastric cancer cells by suppressing betacatenin. Oncol Rep 30(4): 1622-1630, 2013.

17 Kominea A, Konstantinopoulos PA, Kapranos N, Vandoros G, Gkermpesi M, Andricopoulos P, Artelaris S, Savva S, Varakis I, Sotiropoulou-Bonikou $G$ and Papavassiliou AG: Androgen receptor (AR) expression is an independent unfavorable prognostic factor in gastric cancer. $\mathrm{J}$ Cancer Res Clin Oncol 130(5): 253-258, 2004.

18 Tian Y, Wan H, Lin Y, Xie X, Li Z and Tan G: Androgen receptor may be responsible for gender disparity in gastric cancer. Med Hypotheses 80(5): 672-674, 2013. 
$19 \mathrm{Wu}$ CW, Chi CW, Chang TJ, Lui WY and P'Eng F K: Sex hormone receptors in gastric cancer. Cancer 65(6): 1396-1400, 1990 .

20 Nakamura Y, Shimada N, Suzuki T, Imatani A, Sekine H, Ohara $\mathrm{S}$, Shimosegawa $\mathrm{T}$ and Sasano H: In situ androgen production in human gastric carcinoma--androgen synthesizing and metabolizing enzymes. Anticancer Res 26(3A): 1935-1939, 2006.

21 Machowska A, Brzozowski T, Sliwowski Z, Pawlik M, Konturek PC, Pajdo R, Szlachcic A, Drozdowicz D, Schwarz M, Stachura J, Konturek SJ and Pawlik WW: Gastric secretion, proinflammatory cytokines and epidermal growth factor (EGF) in the delayed healing of lingual and gastric ulcerations by testosterone. Inflammopharmacology 16(1): 40-47, 2008.

22 Moghanibashi M, Mohamadynejad P, Rasekhi M, Ghaderi A and Mohammadianpanah M: Polymorphism of estrogen response element in TFF1 gene promoter is associated with an increased susceptibility to gastric cancer. Gene 492(1): 100-103, 2012.

23 Watnick RS: The role of the tumor microenvironment in regulating angiogenesis. Cold Spring Harb Perspect Med 2(12): a006676, 2012.

24 Giatromanolaki A, Sivridis E and Koukourakis MI: The pathology of tumor stromatogenesis. Cancer Biol Ther 6(5): 639-645, 2007.

25 Sivridis E, Giatromanolaki A and Koukourakis MI: "Stromatogenesis" and tumor progression. Int J Surg Pathol 12(1): 1-9, 2004.

26 Ryu WS, Kim JH, Jang YJ, Park SS, Um JW, Park SH, Kim SJ, Mok YJ and Kim CS: Expression of estrogen receptors in gastric cancer and their clinical significance. J Surg Oncol 106(4): 456461, 2012.

27 Wang M, Pan JY, Song GR, Chen HB, An LJ and Qu SX: Altered expression of estrogen receptor alpha and beta in advanced gastric adenocarcinoma: Correlation with prothymosin alpha and clinicopathological parameters. Eur J Surg Oncol 33(2): 195-201, 2007.

28 Lauren P: The two histological main types of gastric carcinoma: Diffuse and so-called intestinal-type carcinoma. An attempt at a histo-clinical classification. Acta Pathol Microbiol Scand 64: 3149, 1965.

29 Nakamura Y, Suzuki T, Nakabayashi M, Endoh M, Sakamoto K, Mikami Y, Moriya T, Ito A, Takahashi S, Yamada S, Arai Y and Sasano H: In situ androgen-producing enzymes in human prostate cancer. Endocr Relat Cancer 12(1): 101-107, 2005.

30 Zhao XH, Gu SZ, Liu SX and Pan BR: Expression of estrogen receptor and estrogen receptor messenger RNA in gastric carcinoma tissues. World J Gastroenterol 9(4): 665-669, 2003.

31 Yang D, Hendifar A, Lenz C, Togawa K, Lenz F, Lurje G, Pohl A, Winder T, Ning Y, Groshen S and Lenz HJ: Survival of metastatic gastric cancer: Significance of age, sex and race/ethnicity. J Gastrointest Oncol 2(2): 77-84, 2011.

32 Singh S, Poulsom R, Wright NA, Sheppard MC and Langman MJ: Differential expression of oestrogen receptor and oestrogen inducible genes in gastric mucosa and cancer. Gut 40(4): 516520, 1997

33 Furukawa $\mathrm{H}$, Iwanaga T, Koyama $\mathrm{H}$ and Taniguchi $\mathrm{H}$ : Effect of sex hormones on carcinogenesis in the stomachs of rats. Cancer Res 42(12): 5181-5182, 1982.

34 Ando $\mathrm{Y}$, Watanabe $\mathrm{H}$, Fujimoto $\mathrm{N}$, Ito $\mathrm{A}$ and Toge $\mathrm{T}$ : Progesterone enhancement of stomach tumor development in SD rats treated with $N$-methyl- $N$ '-nitro- $N$-nitrosoguanidine. Jpn J Cancer Res 86(10): 924-928, 1995.
35 Campbell-Thompson M, Reyher KK and Wilkinson LB: Immunolocalization of estrogen receptor alpha and beta in gastric epithelium and enteric neurons. J Endocrinol 171(1): 6573, 2001.

36 Kurt D, Saruhan BG, Kanay Z, Yokus B, Kanay BE, Unver O and Hatipoglu S: Effect of ovariectomy and female sex hormones administration upon gastric ulceration induced by cold and immobility restraint stress. Saudi Medical Journal 28(7): 1021-1027, 2007.

37 Watanabe H, Okamoto T, Matsuda M, Takahashi T, Ogundigie $\mathrm{PO}$ and Ito A: Effects of sex hormones on induction of intestinal metaplasia by x-irradiation in rats. Acta Pathol Jpn 43(9): 456463, 1993.

38 Ashcroft GS and Ashworth JJ: Potential role of estrogens in wound healing. Am J Clin Dermatol 4(11): 737-743, 2003.

39 Kumral ZN, Memi G, Ercan F and Yegen BC: Estrogen alleviates acetic acid-induced gastric or colonic damage via both ERalpha- and ERbeta-mediated and direct antioxidant mechanisms in rats. Inflammation 37(3): 694-705, 2014.

40 Terasaka S, Aita Y, Inoue A, Hayashi S, Nishigaki M, Aoyagi K, Sasaki H, Wada-Kiyama Y, Sakuma Y, Akaba S, Tanaka J, Sone $\mathrm{H}$, Yonemoto J, Tanji M and Kiyama R: Using a customized DNA microarray for expression profiling of the estrogen-responsive genes to evaluate estrogen activity among natural estrogens and industrial chemicals. Environ Health Persp 112(7): 773-781, 2004.

41 Nylander-Koski O, Kiviluoto T, Puolakkainen P, Kivilaakso E and Mustonen $\mathrm{H}$ : The effect of nitric oxide, growth factors, and estrogen on gastric cell migration. J Surg Res 143(2): 230-237, 2007.

42 Stefano GB, Cadet P, Breton C, Goumon Y, Prevot V, Dessaint JP, Beauvillain JC, Roumier AS, Welters I and Salzet M: Estradiol-stimulated nitric oxide release in human granulocytes is dependent on intracellular calcium transients: Evidence of a cell surface estrogen receptor. Blood 95(12): 3951-3958, 2000.

43 Zhang BG, Du T, Zang MD, Chang Q, Fan ZY, Li JF, Yu BQ, Su LP, Li C, Yan C, Gu QL, Zhu ZG, Yan M and Liu B: Androgen receptor promotes gastric cancer cell migration and invasion via AKT phosphorylation-dependent up-regulation of matrix metalloproteinase 9. Oncotarget 5(21): 10584-10595, 2014.

44 Farinetti A, Tomasi S, Foglio B, Ferraris A, Ponti G, Gotti S, Peretto $P$ and Panzica GC: Testosterone and estradiol differentially affect cell proliferation in the subventricular zone of young adult gonadectomized male and female rats. Neuroscience 286: 162-170, 2015.

45 Barker JM, Ball GF and Balthazart J: Anatomically discrete sex differences and enhancement by testosterone of cell proliferation in the telencephalic ventricle zone of the adult canary brain. $\mathrm{J}$ Chem Neuroanat 55: 1-8, 2014.

46 Stojkovic R, Ivankovic S, Ivankovic D, Attias L, Mantovani A and Fucic A: Testosterone-induced micronuclei and increased nuclear division rate in 1929 cell line expressing the androgen receptor. Toxicol In Vitro 29(5): 1021-1025, 2015.

$47 \mathrm{Hu}$ B, El Hajj N, Sittler S, Lammert N, Barnes R and MeloniEhrig A: Gastric cancer: Classification, histology and application of molecular pathology. J Gastrointest Oncol 3(3): 251-261, 2012.

48 Jiang YA, Zhang YY, Luo HS and Xing SF: Mast cell density and the context of clinicopathological parameters and expression of p185, estrogen receptor, and proliferating cell nuclear antigen in gastric carcinoma. World J Gastroenterol 8(6): 1005-1008, 2002. 
49 Wang X, Ruan Y and Wu Z: [studies of mast cell-mediated cytotoxicity to hepatoma cells in vitro]. Zhonghua Zhong Liu Za Zhi 18(4): 276-278, 1996.

50 Pequeux C, Raymond-Letron I, Blacher S, Boudou F, Adlanmerini M, Fouque MJ, Rochaix P, Noel A, Foidart JM, Krust A, Chambon P, Brouchet L, Arnal JF and Lenfant F: Stromal estrogen receptor-alpha promotes tumor growth by normalizing an increased angiogenesis. Cancer Res 72(12): 3010-3019, 2012.
51 Jensen F, Woudwyk M, Teles A, Woidacki K, Taran F, Costa S, Malfertheiner SF and Zenclussen AC: Estradiol and progesterone regulate the migration of mast cells from the periphery to the uterus and induce their maturation and degranulation. PLoS One 5(12): e14409, 2010.

Received November 10, 2016

Revised December 9, 2016

Accepted December 16, 2016 